\title{
酸化ほう素を添加したコークスの焼結と 黒鉛化におよぼす加圧焼成温度の影響
}

\author{
萩尾剛* ・松下泰広** \\ 小林和夫* . 本田英昌 ${ }^{*}$
}

（昭和 52 年 2 月 18 日受理）

Effect of Hot-pressing Temperature on Sintering and Graphitization of Coke with $\mathrm{B}_{2} \mathrm{O}_{3}$ Addition

Tsuyoshi HAGIO*, Yasuhiro MATSUSHITA**, Kazuo KOBAYASHI*, and Hidemasa HONDA*

\footnotetext{
* National Industrial Research Institute of Kyushu, Tosu, Kyushu, Japan

** Nippon Crucible Co., Ltd., Inada, Higashiosaka, Osaka, Japan
}

\begin{abstract}
Effect of hot-pressing temperature was investigated on some properties of polycrystalline coke compacts made from calcined pitch coke powder with $10 \% \mathrm{~B}_{2} \mathrm{O}_{3}$ addition at various temperatures from 1200 to $2200{ }^{\circ} \mathrm{C}$ under a pressure of $200 \mathrm{~kg} / \mathrm{cm}^{2}$. Bulk density was almost constant as $1.6 \mathrm{~g} / \mathrm{cm}^{3}$ up to $1800{ }^{\circ} \mathrm{C}$, and increased rapidly to about $2.0 \mathrm{~g} / \mathrm{cc}$ above $2000{ }^{\circ} \mathrm{C}$. Mechanical strength once decreased at temperature range from 1600 to $1800{ }^{\circ} \mathrm{C}$, and it increased again above $2000{ }^{\circ} \mathrm{C}$. Graphitization proceeded remarkably above $2000{ }^{\circ} \mathrm{C} . \mathrm{B}_{4} \mathrm{C}$ was formed at $1600{ }^{\circ} \mathrm{C}$ and amount of $\mathrm{B}_{4} \mathrm{C}$ decreased with increase of temperature.

The hot-pressed compacts could be classified into three types. The first is the one made below $1400{ }^{\circ} \mathrm{C}$ in which coke particles adhered each other with $\mathrm{B}_{2} \mathrm{O}_{3}$ glass phase, the second is the one made between 1600 and $1800^{\circ} \mathrm{C}$ which consist of the mixture of coke particle and small amount of $\mathrm{B}_{4} \mathrm{C}$ exist independently, and the last is the one made above $2000^{\circ} \mathrm{C}$ of which boron is considered to give strong influence for sintering and graphitization of coke by its diffusion into coke structure.
\end{abstract}

\section{1. 緒一言}

一般に炭素材は $1000{ }^{\circ} \mathrm{C}$ ない $1300{ }^{\circ} \mathrm{C}$ で焼成したコー クスに 30〜40\%ピッチをバインダーとして混練し, 成 形，焼成することにより製造されている。その製造工程 においてピッチバインダーを用いるのは, 粉末治金ある いは割業などで採用されている粉末焼結法がュークスに 対しては適用できないことによる. その原因として，コ 一スを構成する炭素原子の自己拡散係数が小さいことが あげられる。

バインダーレス炭素成形体に関する研究報告はまだ数 少なく, 最近, Chard and Niesz ${ }^{1)}$ がHIP (Hot Isostatic Prss）法により, 圧力約 $1000 \mathrm{~kg} / \mathrm{cm}^{2}$, 温度 $2200 \sim$ $2500{ }^{\circ} \mathrm{C}$ の条件で高密度かつ高強度黒鉛成形体の製造を 報告している。また, 稲垣ら ${ }^{2), 3)}$ は各種原料炭素を 5 kbar の加圧下で約 $2000^{\circ} \mathrm{C}$ の加熱処理を行ない，黒鉛 焼結体を得ているが, 高圧による実験の場合は装置から

*九州工業技術試験所：佐賀県鳥栖市宿町

** 日本ルツボ (株)：大阪府東大阪市稲田 925
くる制限があり，試料寸法はかなり小さい。Neproshin

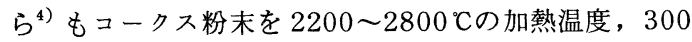
$\mathrm{kg} / \mathrm{cm}^{2}$ の加圧で焼結を試みているが抗折力は最大約 $20 \mathrm{~kg} / \mathrm{cm}^{2}$ であり, 焼結性は悪い。

さきに筆者ら ${ }^{5), 6)}$ は,コークス粉末に酸化ほう素を少 量添加し， $200 \mathrm{~kg} / \mathrm{cm}^{2}$ の加圧下でこれを $2200{ }^{\circ} \mathrm{C}$ で焼 成することにより, かさ密度 2.0 以上の高密度黒鉛焼結 体を製造し得ることを報告した。特に酸化ほう素の添加 量が約 $10 \mathrm{wt} \%$ のき, 最大圧縮強度 $600 \mathrm{~kg} / \mathrm{cm}^{2}$ の焼 結体を得た。

本報告は, 酸化ほう素を添加したコークス粉末の加圧 下焼結に関するものであり, その処理温度を変化させて 得られた成形体の物性の変化を検討し, これとコークス 単味で加圧下焼成して得られた成形体の物性を比較する ことにより，その焼結現象について 2,3 の知見を得たの で報告する。

\section{2. 実験方法}

\section{1 原 料}


1977 (No. 89) 酸化ほう素を添加したコークスの焼結と黒鉛化におよぼす加圧焼成温度の影響

用いたコークスは約 $1300^{\circ} \mathrm{C} の$ 仮焼ピッチュークス(以 下ュークスという)で，これを $149 \mu \mathrm{m}$ 以下に粉砕し， さらにその $15 \mathrm{~g}$ ずつを擂擯機で約 30 分間摩砕した。つ いでこれに酸化ほう素を水溶添加し，乾燥したものを実 験試料(以下B添加コークスという)とした。酸化ほう素の 添加量は, 先の報告 ${ }^{5}$ ) で最大強度を示した $10 \mathrm{wt} \%$ (外掛 け) と一定にした。比較のため, 酸化ほう素を加えないコ 一クス (以下コークス単味という)の試料も準備した。

\section{2 成形体の製造}

各原料は内径 $30 \mathrm{~mm}$ の黒鉛ダイスに充填し, Fig. 1 に 示す高周波誘導加熱装置に装入し, 加圧下で所定温度ま で昇温した。昇温中に生じる試料の収縮は同図に示すダ イヤルゲージで測定した。圧力は $200 \mathrm{~kg} / \mathrm{cm}^{2}$ とし, 昇 温速度は約 1 時間で室温から $2000{ }^{\circ} \mathrm{C}$ になように設定 した。 $1000{ }^{\circ} \mathrm{C}$ での温度測定は Pt - PtRh 熱電対によ り, $1000^{\circ} \mathrm{C}$ 以上は光高温計で測定した。処理温度とし ては $1200,1400,1600,1800,2000$ および $2200^{\circ} \mathrm{C}$ を選び, 各温度での保持時間は 30 分とした。各温度で 保持した後, 加熱を止め, 約 15 分間加圧の状態を保っ た。その後, 圧力を取り除き, 冷却後試料を取り出した。 得られた成形体は径 $30 \mathrm{~mm}$, 厚みは 10〜 $14 \mathrm{~mm}$ の大き さであった。

\section{3 物性測定}

成形体のかさ密度は外寸法から求めた体積と重量から 計算した。機械的強度はインストロン式オートグラフで 測定し, 成形体製造時の加圧方向の破壊強度を求めた。 変位速度は $1 \mathrm{~mm} /$ 分とした。曲げ試験は約 $10 \times 10 \times 30$ $\mathrm{mm}$ の試験片を 3 点法により行い, スパン距離は $20 \mathrm{~mm}$ とした。圧縮試験は約 $10 \times 10 \times 10 \mathrm{~mm}$ の試験片で行っ た。強度值は同一試料につき 2 回測定し, その平均值で 求めた。

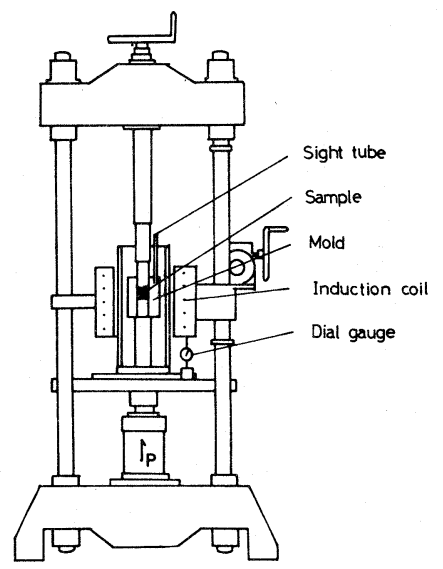

Fig. 1 Hot-press apparatus.

\section{$2.4 X$ 線回折法および化学分析}

$\mathrm{X}$ 線回折は理学電機製ロータフレックスを用いた。 $\mathrm{X}$ 線管球の電圧, 電流はそれぞれ $35 \mathrm{kV}, 30 \mathrm{~mA}$ とし, $\mathrm{CuK}_{\alpha}$ を用いた。成型体中のコークスのX線パラメータ 一の測定は学振法 ${ }^{7)}$ に準じて行い, 面間隔 $d_{(002)}$, 見掛け の結晶子の大きさ $L_{c(002)}$, および (112) 回折線につ いて調べた。内部標準シリコンの量は $10 \mathrm{wt} \%$ とした。 成形体中の $\mathrm{B}_{4} \mathrm{C}$ 定量は, 内部標準としてシリコンを 3 wt \% 添加し, カウント法により $\mathrm{B}_{4} \mathrm{C}(021)$ 回折線とシ リコン (311) 回折線との強度比を求め, あらかじめ作 成した検量線により求めた。成形体中のほう素量は, JIS R7223に準じ, 化学分析により求めた。

\section{3. 実験 結果}

\section{1 試料の収縮}

成形体の製造時に測定した試料の代表的な収縮曲線を Fig. 2 に示す。曲線 a はB添加コークスの収縮曲線を, 曲線 b はコークス単味の収縮曲線を示す。これらの収縮 には黒鉛パンチ棒の熱膨張も加味されているので, 試料

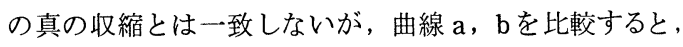
$\mathrm{B}$ 添加コークスは約 $150^{\circ} \mathrm{C}$ 付近で収縮があり, さらに約 $1900^{\circ} \mathrm{C}$ 付近から大きな収縮が始まっていることがわかる。

\section{2 密度および機械的強度}

Fig. 3 は処理温度に伴う成形体のかさ密度の変化を示 す。コークス単味の成形体のかさ密度は処理温度の増加 とともにわずかながら増加しているのに比べ, B添加コ 一クスの成形体は $1800^{\circ} \mathrm{C}$ ま゙゙およそ一定した $1.6 \mathrm{~g} /$ $\mathrm{cm}^{3}$ のかさ密度を示しており, $2000^{\circ} \mathrm{C}$ になる急激な増 加を示し, $2200^{\circ} \mathrm{C}$ ではさらに大きく約 $2.0 \mathrm{~g} / \mathrm{cm}^{3}$ のかさ

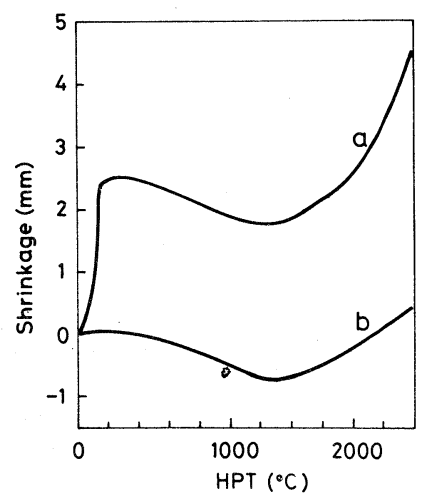

Fig. 2 Shrinkage curves of the samples with temperature under hotpressing.

a: coke with $10 \% \mathrm{~B}_{2} \mathrm{O}_{3}$ addition b: coke with no addition 


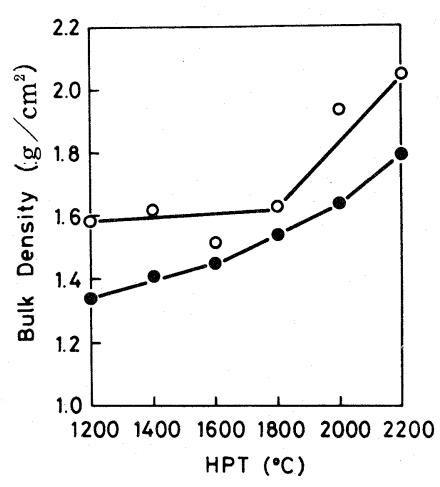

Fig. 3 Change of bulk density of the compacts with hot-pressing temperature.

$O$ : coke with $10 \% \mathrm{~B}_{2} \mathrm{O}_{3}$ addition : coke with no addition
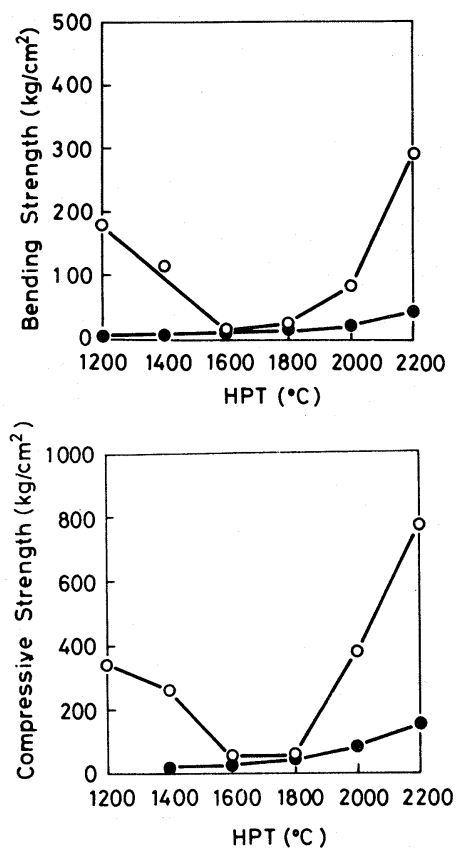

Fig. 4 Change of bending strength and compressive strength of the compacts with hot-pressing temperature.

$\bigcirc$ : coke with $10 \% \mathrm{~B}_{2} \mathrm{O}_{3}$ addition

- : coke with no addition

密度になる。また, $1800^{\circ} \mathrm{C}$ 以下のB添加コークスの成形 体は, 同温度のコークス単味の成形体よりも大きな密度 を示している。Fig. 4 は, 処理温度に伴う成形体の曲げ 強度および圧縮強度の変化を示す。両強度とも同じ傾向 を示し, コークス単味の成形体の強度が処理温度の上昇
とともにわずかながら増加するのに較べ，B添加コーク スの成形体は全く異なった变化を示す。1200〜 $1400{ }^{\circ} \mathrm{C}$ では約 $300 \mathrm{~kg} / \mathrm{cm}^{2}$ の圧縮強度を持っているが， 1600 〜 $1800{ }^{\circ} \mathrm{C}$ になるその強度は低下し, コークス単味の成 形体と同程度の強度となる。それは粉末が単に成形体を 形成しているだけのもので, 手で圧縮することにより容

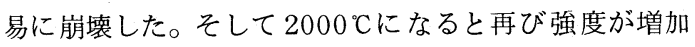
しており，2200 ${ }^{\circ} \mathrm{C}$ はさらに増大し, 曲げ強度 $300 \mathrm{~kg}$ $/ \mathrm{cm}^{2}$, 圧縮強度 $780 \mathrm{~kg} / \mathrm{cm}^{2}$ の值を示す成形体となっ た。

\section{3 コークスのX線パラメーター}

Fig. 5 は得られた成形体中のコークスの処理温度に伴 う面間隔 $d_{(002)}$ の変化を示す。 $\mathrm{B}$ 添加コークスの面間隔 は, $1800{ }^{\circ} \mathrm{C}$ までは同温度で処理されたコークス単味の 面間隔とほぼ一致しているが， 2000 C 以上では急激な 減少を示し, 2000 ㄷでは $3.366 \AA$, 2200 ㄷでは $3.356 \AA$ の値となる。その $2000^{\circ} \mathrm{C}$ における面間隔は, 常圧下, $2800^{\circ} \mathrm{C}$ で熱処理されたュークス単味の面間隔に相当す

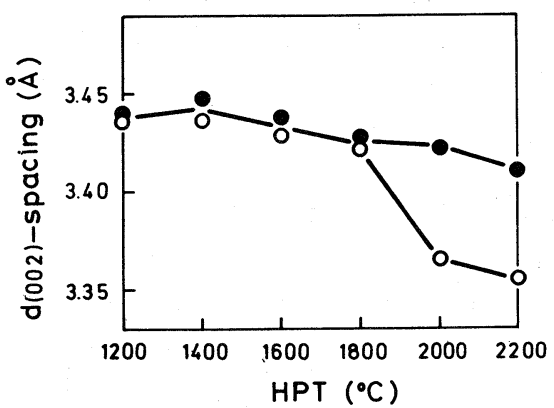

Fig. 5 Change of $d_{(002)}$ spacing of coke with hot-pressing temperature.

$\mathrm{O}$ : coke with $10 \% \mathrm{~B}_{2} \mathrm{O}_{3}$ addition

: coke with no addition

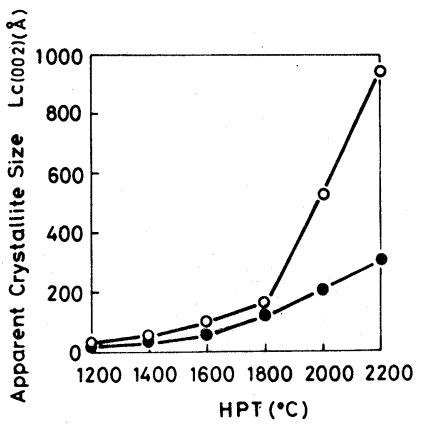

Fig. 6 Change of apparent crystallite size, $L_{c(002)}$, of coke with hot-pressing temperature.

$\mathrm{O}$ : coke with $10 \% \mathrm{~B}_{2} \mathrm{O}_{3}$ addition

- : coke with no addition 
1977 (No. 89) 酸化ほう素を添加したコークスの焼結と黒鉛化におよぼす加圧焼成温度の影響

る。Fig. 6 は処理温度の変化に伴う見掛けの結晶子の大 きさ $L_{c(002)}$ の変化を示す。見掛けの結晶子の大きさも面 間隔と同様, B添加コークスは $2000{ }^{\circ} \mathrm{C}$ 以上で増大し, $2200{ }^{\circ} \mathrm{C}$ では約 $950 \AA$ Aの大きさを示す。また, B 添加コ

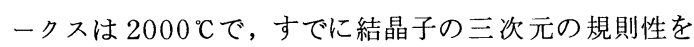
表わす (112) 回折線が顕著に認められた。この $2000{ }^{\circ} \mathrm{C}$ のB添加コークスにおける (112) 回折線は, 常圧下で $2600^{\circ} \mathrm{C}$ 処理されたコークス単味のそれに相当する発達 を示していた。

\section{$3.4 \quad B_{4} C$ 量とほう素量}

$\mathrm{B}$ 添加ュークスの成形体のX 線回折図形を測定し, コ ークス以外の化合物の生成を確かめた。1200 $1400^{\circ} \mathrm{C}$ では酸化ほう素の (310) 回折線が， 1600 ○ 以上では $\mathrm{B}_{4} \mathrm{C}$ の (021) 回折線が認められたが, 他の回折線は認め られなかった。Fig.7はX線回折により求めた処理温度 に伴う B 添加コークス成形体中の $\mathrm{B}_{4} \mathrm{C}$ 含有量の変化を示 す。 $1600^{\circ} \mathrm{C}$ での $\mathrm{B}_{4} \mathrm{C}$ 量は約 $2.6 \mathrm{wt} \%$ であり, その処理 温度の上昇とともに $\mathrm{B}_{4} \mathrm{C}$ 量は減少している。そして 2200 ${ }^{\circ} \mathrm{C}$ では約 $1.2 \mathrm{wt} \%$ であった。Fig. 8 は化学分析により求 めた成形体中に残存する全ほう素量と, X 線回折より求 めた $\mathrm{B}_{4} \mathrm{C}$ として存在するほう素量の処理温度に伴う変化

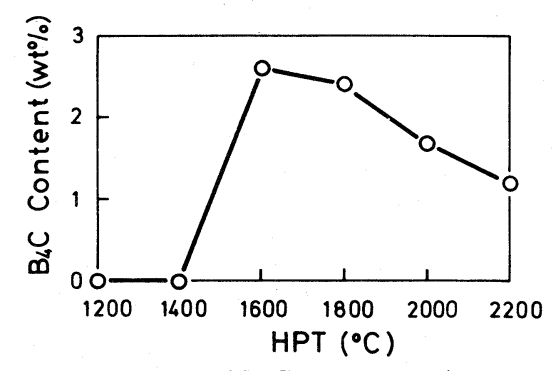

Fig. 7 Change of $\mathrm{B}_{4} \mathrm{C}$ content in the compacts with hot-pressing temperature.

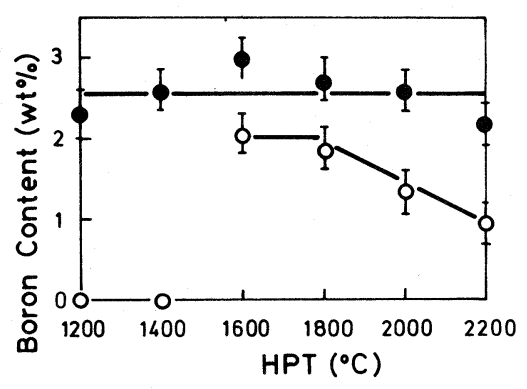

Fig. 8 Change of boron content in the compacts with hot-pressing temperature.

- total boron content by chemical analysis

$\mathrm{O}$ : content of boron forming $\mathrm{B}_{4} \mathrm{C}$ estimated by X-ray analysis
を示す。成形体中の全ほう素量は全処理温度範囲でほぼ 一定した值を示している。 $1600 \sim 1800{ }^{\circ} \mathrm{C} て ゙ は ， \mathrm{~B}_{4} \mathrm{C}$ 中 のほう素量は残存全ほう素量に近い值を示しており，こ の温度範囲ではほう素は大部分 $\mathrm{B}_{4} \mathrm{C}$ として存在している ことが推定できる。

\section{4. 考察}

コークス単味の成形体はその処理温度の増加とともに

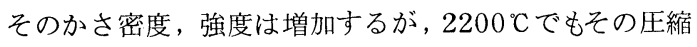
強度は約 $150 \mathrm{~kg} / \mathrm{cm}^{2}$ と低く, 殆んど焼結していなかっ た。それに対してB添加コークスは $2000^{\circ} \mathrm{C}$ 以上の温度 で焼結していた。そしてB添加コークス成形体はその処 理温度により 3 種類に分けられた。

$1200 \sim 1400^{\circ} \mathrm{C}$ での成形体はュークスと酸化ほう素か らなるものであり, 添加した酸化ほう素がュークスのバ インダーとして作用しているものと考えられる。その理 由として以下に述べることがあげられる。すなわち,

Fig. 7 やFig. 8 のX線回折や化学分析の結果から, この 温度範井では, 添加した酸化ほう素はマトリックスのコ 一クスと末反応であり，そのまま酸化ほう素の形で存在 していることが判る。さらに, Fig. 5 やFig. 6 のX線パ ラメーターの変化から, 酸化崩素の添加は同温度範囲で はコークスの構造に何ら影響を与えず, 同温度でのコー クス単味のX線パラメーターとほぼ同一であることが判 る。また, Fig. 1 に見られる約 $150^{\circ} \mathrm{C}$ 付近の収縮は, 水 溶液の形で添加した酸化ほう素の脱水あるいは溶融にと もならコークス粒子の再配列によるものと考えられる。 そして, その酸化ほう素がコークス粒のバインダーとし て作用し，Fig. 4 に示すように強度のある成形体を作っ ていることが判る。

$1600 \sim 1800{ }^{\circ} \mathrm{C}$ の゙成形体は強度のないコークスと少 量の $\mathrm{B}_{4} \mathrm{C}$ からなる王粉成形体であると考えられる。すな わち, この温度範囲では Fig. 7 やFig. 8 のX線回折や化 学分析の結果から判るように, 添加した酸化ほう素はコ 一クスと反応し， $\mathrm{B}_{4} \mathrm{C}$ が生成している。そして，その成 形体中のほう素の大部分は $\mathrm{B}_{4} \mathrm{C}$ の形で存在していると考 えられる。さらに, この成形体の強度はFig. 4 に示され るように, 同温度で処理されたコークス単味のものと異 ならず，それはコークスと $\mathrm{B}_{4} \mathrm{C}$ の単なる圧粉成形体であ ることが判る。また, 成形体中のコークスのX線パラメ ーターも同温度で処理されたコークス単味のものと殆ん ど変化なく, $2000^{\circ} \mathrm{C}$ 以上で処理されて得られた $\mathrm{B}$ 添加 コークス成形体中のコークスに見られたような著しい面 間隔, $d_{(002)}$, の減少はなかった。

$2000 \sim 2200^{\circ} \mathrm{C}$ での成形体は, 大きなかさ密度と強度 を持っており, Fig. 2 の約 $1900^{\circ} \mathrm{C}$ 付近からの大きな収 
縮は, $1900^{\circ} \mathrm{C}$ 付近より焼結が進行し始めたことを示し ている。この成形体において特徵的なことは, コークス のX線パラメーターに大きな変化が生じていることと， $\mathrm{B}_{4} \mathrm{C}$ の存在量が減少していることである。ほう素が黒鉛 中に固溶しX線パラメーターに変化を与えることは，す

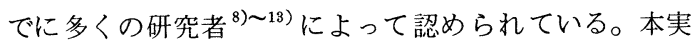
験においても $2000^{\circ} \mathrm{C}$ 以上の温度でほう素がュークス中 に拡散, 固溶することにより, X 線パラメーターに変化 が生じたといえる。しかも面間隔の減少, 結晶子の増大 さらに(112) 回折線の発達からみて黒鉛構造が著しく改 善されていることが判る。一方, 黒鉛化触媒として金属

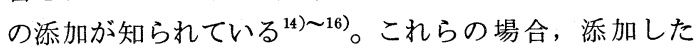
金属がコークスと反応し, 炭化金属を生成し, その炭化 金属から黒鉛構造成分が析出することが知られている。 そしてその場合にはX線 $(00 l)$ 回折線に黒鉛構造成分 によるシャープなピークが出現し, 複合図形を示すこと が知られているが, 本実験の場合にはそのような現象は 全く観察されず, 処理温度とともに $(00 l)$ 回折線が単一 ピークで除々に黒鉛構造へ移行していく。このことは, ほう素は他の金属と全く異なる効果をおよぼしているも のと考えられる。㹸えらく固溶にともなうほう素の拡散 がコークス構造の秩序化に何らかの影響をあたえている ものと推定できる。本実験の場合, このほう素の大部分 は一度生成した $\mathrm{B}_{4} \mathrm{C}$ から供給されていると考えられ, さ らに加圧下ではこのほう素の拡散現象がコークス構造中 の炭素原子の移動を助長し, 焼結が生じたものと推定さ れる。

以上のように，処理温度を変化させて製造した B 添加 コークス成形体の物性を調べた結果, 強度のある焼結体 を得るには $2000^{\circ} \mathrm{C}$ 以上の処理温度が必要であることが わかった。そして, その成形体の密度や強度の增大はほ う素のコークス中への拡散と密接な関係のあることがわ かった。しかし, その焼結機構の議論については, より 詳細な実験が必要である。

\section{5. まとめ}

コークスに酸化ほう素を添加し，加圧下で1200 $2200^{\circ} \mathrm{C}$ の各温度で処理し成形体を製造した。その物性 やュークスのX線パラメーターを測定し, 処理温度の影 響を調べた。得られた結果は次のとおりである。

1) $1200 \sim 1400{ }^{\circ} \mathrm{C}$ で得られた成形体は, 酸化ほう素 がコークス粒のバインダーとして作用している成形体で あった。

2) $1600 \sim 1800{ }^{\circ} \mathrm{C}$ で得られた成形体は，単にコーク スと $\mathrm{B}_{4} \mathrm{C}$ の混合成形体で, 焼結は認められなかった。

3） $2000 \sim 2200{ }^{\circ} \mathrm{C}$ で得られた成形体は, 密度, 強度 の大きな焼結体であった。そして, その焼結はュークス 中へのほう素の拡散と密接な関係のあることがわかった。

\section{文献}

1) Chard W.C. and Niesz D. E. Abstract for the 11 th Carbon Conf. (1973)

2) 稲垣, 中, 粉体および粉末治金, 22, 87, (1975)

3) 稲垣, 三輪, 炭素, No.85, 69, (1976)

4) Neproshin E. I. et al, Sov. Powder Metall. Met. Ceram. V13, N3, Mar., 210 (1974)

5) 小林, 松下, 小川, 本田, 炭素, No. 82,118 , (1975)

6) 松下, 萩尾, 小林, 本田, 炭素, No. 86,112 , (1976)

7) 炭素材料研究会, “炭素材料入門”, 184 (1972)

8) F. Tombrel, Rev. Hautes. Tempér. et Réfract., t. 3, 79 (1966)

9) J. A. Turnbull et al, Carbon, 3, 387 (1966)

10) W. V. Kotlensky, Carbon, 5, 409 (1967)

11) C. E. Lowell, J. Amer. Ceram. Soc., 50, No 3, 142 (1967)

12) S. Marinković et al, Carbon, 7, 185 (1969)

13) Jean-Pierre Rouchy et Jacques Méring, C. R. Acad. Sc. Paris, 277, série C, 533 (1973)

14) 石川, 鈎, 水谷, 吉沢, 炭素, No.41, 18(1965)

15) 山田, 炭素, No.43, 18(1965)

16) 大谷, 大谷, 宇津木, 炭素, No.68, 10(1972) 